\title{
The variability of wood density and compression strength of Norway spruce (Picea abies /L./ Karst.) within the stem
}

\author{
*Petr Horáček ${ }^{1}$, Marek Fajstavr¹, Marko Stojanović ${ }^{1}$ \\ 1) Global Change Research Institute CAS, Bèlidla 986/4a, CZ-603 00 Brno, Czech Republic, e-mail: \\ horacek.p@czechglobe.cz, fajstavr.m@czechglobe.cz, stojanovic.m@czechglobe.cz
}

\begin{abstract}
Horáček P., Fajstavr M., Stojanović M. 2017: The variability of wood density and compression strength of Norway spruce (Picea abies /L./ Karst.) within the stem - Beskydy, 10 (1,2): $17-26$
\end{abstract}

This study relates to the variability of wood density and compression strength parallel to grain within the stem of spruce trees (Picea abies /L./ Karst.). The sample tree originated from the Giant Mountains and was an adult autochtonous mountain spruce. The properties were analysed for wood that formed between 1850 and 1990 along (1) the north-south oriented radius and along (2) the stem height on test specimens with the following dimensions: $20 \times 20 \times 30 \mathrm{~mm}$, prepared from logs taken from the stem base at distances of 2, 4, 6, 10, 14, 20, 22, 24 and $26 \mathrm{~m}$. In individual sections, the properties of the samples oriented in the north or south direction did not differ, while the effect of different ages on the properties showed statistically significant differences at each orientation $(\mathrm{p}<0.05)$. Along the radius, the properties showed an increasing trend in tree-rings that developed between 1850 and 1940 with a slight decrease in the following years. The coefficient of variation in various decades was 1-7\% (wood density) and 3-15\% (wood compression strength). Along the stem height, the properties gradually increased to a height of $20 \mathrm{~m}$, while the increase in values was more pronounced in the $22-26 \mathrm{~m}$ interval. The variability of the wood properties along the stem height corresponded to the variability of the properties along the stem radius. A linear dependence between wood strength and density was demonstrated. Compared to what had been previously written, wood density showed a greater impact, probably due to the biomechanical optimization of the stem with regard to mechanical wind and snow loads in the mountains.

Keywords: Norway spruce, wood density, compression strength

\section{Introduction}

Wood properties determine the resulting quality of wood products. Wood density is considered an indicator of wood quality; it depends on the anatomical structure and affects the strength characteristics of the wood. The causal relationships between wood density and wood anatomical structure have been studied in a number of studies (Luostarinen 2017). However, wood density does more than serve to monitor the response of trees to changing environmental conditions and to easily express anatomical structure; it is also a measure of the utility properties of wood, especially certain mechanical properties of wood such as strength and flexibility. Wood density is the best and easiest index to determine the strength of wood without the presence of defects; wood strength generally increases with wood density (Kollmann 1951, Bodig and Jayne 1982, Tsoumis 1991). Higher wood density exists when there is a higher proportion of wood substance in the respective volume of wood. At the cellular level, the cause is the increased thickness of cell walls and the decreased lateral dimension of the cell or lumen. 
Increased wood density results in a greater ability of the material to resist the actions of forces, i.e. the wood strength increases.

The strength of the correlation between density and the strength of wood varies, depending both on different ways of stressing the wood and different types of wood. This relationship is generally expressed by a power function (Bodig and Jayne 1982, Forest Products Laboratory 1999); in most cases, however, the course is linear (Tsoumis 1991). The close dependence between wood density and the mechanical properties of wood piqued our interest in understanding and characterizing wood density within trees.

There are distinct differences between trees of a similar species and even within a single tree, which occur both in the horizontal direction (from the pith to the bark) and the vertical direction (from the base to the top). The greatest variability in wood density is typically found along the radius in the radial direction (Bodig and Jayne 1982). Therefore, the variability within a tree can be traced (1) in the radial direction along the stem radius from the pith to the cambium or (2) in the longitudinal direction from the stem base to the top (Panshin and de Zeeuw 1980).

For spruce, the variability in wood density of tree-rings in the radial direction is known (Olesen 1977, Petty et al. 1990, Saranpää 1994, 2003). Wood density from the pith first decreases and reaches a minimum value around tree-rings 1020 (Danborg 1994). Then, it gradually increases with age (Olesen 1977, Petty et. al 1990, Jaakkola et al. 2005). The variability of wood density in the longitudinal direction has been studied much less. Typically, one of the following approaches is used: (1) the wood density of treerings calculated from the pith to the cambium (the age of the cambium), (2) the wood density of tree-rings calculated from the cambium to the pith (calendar years), (3) the wood density of log discs (Jyske et al. 2008). Some studies describe the increase in wood density of treerings with the same age of cambium (the same number of tree-rings from the pith, approach No. 1) from the base to the top of the stem (Saranpää 2003, Molteberg and Høibø 2006). Most studies, however, are based on the average wood density of the discs (approach No. 3) and the results are unclear (Hakkila 1966, Olesen 1976, Johansson 1993, Repola 2006). The variability of the strength characteristics within the stem is subsequently evaluated using the relationship between the density of wood and its strength
(Bodig and Jayne 1982). The variability of wood properties between trees ranges around 5-20\% (Jyske et al. 2008) and is much smaller than the variability of properties within a stem. Variability among stems is mainly due to genetic variability (Bergstedt and Olesen 2000); variability within a stem is given by different stem thicknesses and the number of tree-rings along the stem height (Wilhelmsson et al. 2002).

The present work addresses and evaluates the spatial distribution of wood density and selected mechanical properties of compressive strength in the direction that the fibres are oriented, both along the radius and the stem height. It compares the results of possible different approaches for assessing the variability of wood properties - at the same distance from the pith, expressed by the age of the tree-ring (approach No. 1), within the same tree-ring created in a given year (approach No. 2), and the average value for the log disc. The aim of the work is to verify the current knowledge surrounding the spatial distribution of wood density and strength within the stem. The work also follows a detailed anatomical analysis of tracheid morphometric parameters that influence and modify the density and strength of wood (Gryc 2003).

\section{Materials and methodology}

The analysis relates to one sample of autochthonous spruce growing in the Giant Mountains, near Labský důl (LZ Vrchlabí, the forest district of Labská, stand 103 C17V), at an altitude of $1040 \mathrm{~m}$. In 1997, the age of the tree was 157 years, its height was $33 \mathrm{~m}$ and its thickness at a height of $1.3 \mathrm{~m}$ was $75 \mathrm{~cm}$.

From the spruce sample, 12 log discs with a thickness of $100 \mathrm{~mm}$ were available. These were taken at distances of 2, 4, 6, 10, 14, 20, 22, 24 and $26 \mathrm{~m}$ from the stem base (sections). The logs were used to produce specimens with dimensions of $100 \mathrm{~mm}$ in the longitudinal direction, $25 \mathrm{~mm}$ in the tangential direction and with the disc radius in the radial direction having a north-south orientation along the log radius (Fig. 1). These specimens were cut along the height into two parts being $50 \mathrm{~mm}$ high, each of which was used to monitor the wood density and wood compressive strength parallel to grain with two replications. In total, we measured 302 specimens: 160 specimens from the radius with a northern orientation and 142 specimens from the radius with a southern orientation. 


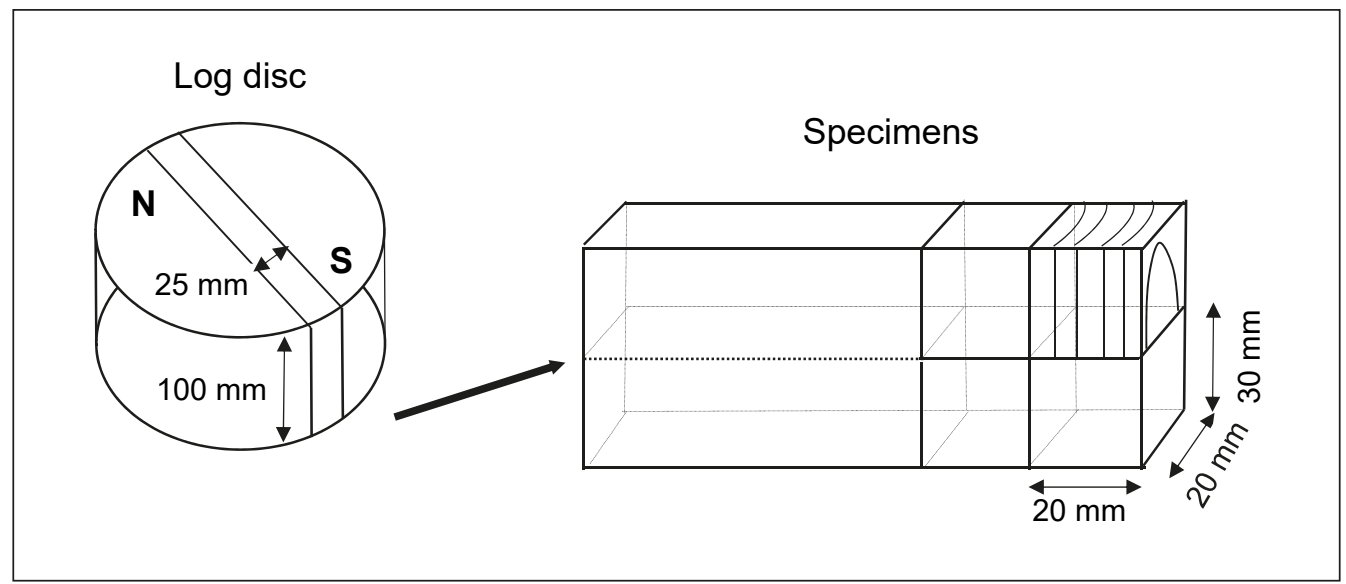

Fig. 1: An illustration of sample selection for testing wood properties along the stem radius (in the north-south direction).

The individual specimens shaped like rectangular prisms were cut from the sample sequentially in the radial direction from the cambium to the pith so that the boundary of the tree-rings made an angle of less than $10^{\circ}$ toward the tangential plane. The dimensions of the specimens corresponded to standards ČSN 490108 and ČSN 490110 , i.e. $30 \times 20 \times 20 \mathrm{~mm}$ (longitudinal $\mathrm{x}$ radial $\mathrm{x}$ tangential direction). Due to the effect of age on the widths of the tree-rings, each specimen contained about 5 (juvenile wood) to 20 (mature wood) tree-rings, which corresponds to an average tree-ring width of $1-4 \mathrm{~mm}$. Each specimen was subsequently assigned an average calendar year corresponding to the formation of the average tree-ring of the specimen and the average cambial age. The tree-rings used to assign the calendar year were calculated from the cambium to the pith; the tree-rings used to assign the cambial age were calculated from the pith to the cambium. For example, if the specimen contained tree-rings created from 19781996, the average year was therefore calculated as the average of these years, i.e. 1987. This year (or age) was then assigned measured values on the specimen - wood density and compression strength parallel to grain, determined according to standards ČSN 490108 and ČSN 490110. The equilibrium moisture content of the samples at the time of testing was determined at 9-10\% (when using the weighting method according to ČSN 490103).

The measured data was then grouped into classes by decade within the interval of 18501990 (calendar years), i.e. 0-150 years (cambial age). The given decade was assigned years (age) falling within an interval of \pm 5 years. 1989 was thus assigned to the decade 1990; 1985 was assigned to both decades 1990 and 1980. The arithmetic mean of the measured variables was finally calculated for each decade. The arithmetic mean of the measured variables was also calculated for each section along the stem height. The data were evaluated separately for the northern and southern orientations. The paired t-test analysis was used to prove the statistically significant differences between the results of the methods used, both within various height sections species and both orientations.

\section{Results and discussion}

\section{Wood density - distribution along the stem radius and height}

The average wood density for the whole tree calculated from all measured specimens was $378 \mathrm{~kg} \cdot \mathrm{m}^{-3}$ ( $\mathrm{Sx}=23.7 \mathrm{~kg} \cdot \mathrm{m}^{-3}, \mathrm{Vx}=6.3 \%$ ). This value corresponds to the lower limit of the literal data for dry wood for which, at a moisture content of $12 \%$, various authors indicate a density of 330-680 kg.m ${ }^{-3}$ with a mean value of 430 470 kg.m ${ }^{-3}$ (Vorreiter 1949, Kollman 1951). Irrespective of the section height, the determined variability of wood density was lower compared to the literal data, which assume $\mathrm{Vx}= \pm 10 \%$.

The results of spatial variability in wood density within the stem differed according to the methodological approach used. In the case of assigning the density of wood to the age of the cambium (tree-rings calculated from the pith), the individual height sections showed significantly 


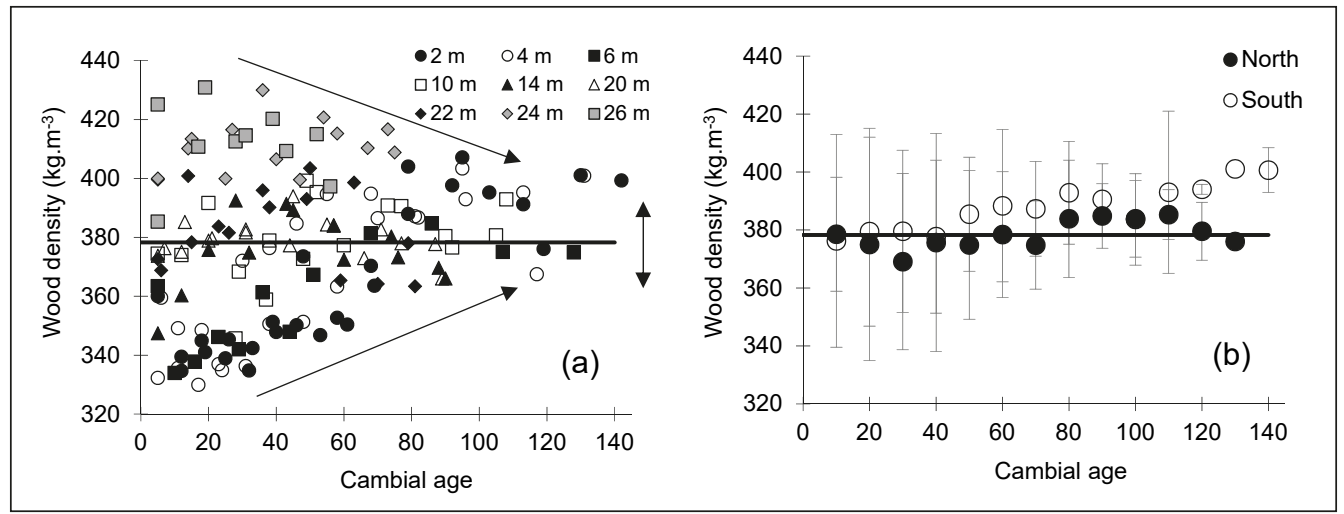

Fig. 2: Variability in wood density along the stem radius for an average age of the tree-ring - (a) in various height sections, (b) average values from all height sections with northern and southern orientation (the lines represent \pm 1 standard deviation).

different age trends (Fig. 2a). For logs taken from the stem bottom at heights of $2-6 \mathrm{~m}$, it is true that wood density increased with age. In the central part of the stem, at heights of 10-20 m, the density was independent of age and ranged around the average value. In the crown part of the stem, at heights of $22-26 \mathrm{~m}$, a decrease in wood density with age is noticeable. It can be stated that the younger the wood, the greater the variability along the stem height $(\mathrm{Vx}=8-10 \%)$; variability decreases with increasing age $(\mathrm{Vx}=$ $2-4 \%)$. The different size of samples sets is one of potential explanation. With decreased variability, wood density approximates the average value with increasing age, whereas its value along the stem height is basically constant from the age of about 80 years. The average values of wood density are also independent of age (Fig. $2 \mathrm{~b}$ ). With higher age, however, the course on the north and south sides of the stem is increasingly different (the difference is statistically very significant, $\mathrm{p}<0.001$ ), which suggests biomechanical optimization.

In the case of assigning wood density to a calendar year (rings calculated from the cambium), the individual height sections showed the same pattern with the general trend of the variability in wood density along the radius (FrimbongMensah 1987) - a gradual increase in wood density during the first few decades followed by a more or less constant course and completed with decreasing values in the area near the bark (Fig. 3a). The only difference between the height sections can be found in the crown part, where wood density at a height of $24-26 \mathrm{~m}$ was noticeably greater than in other parts of the stem. We assume, that such increase in wood density along the stem might be due to presence of reaction wood. The differences between the northern and southern orientation of the samples were statistically significant $(p<0.05)$.

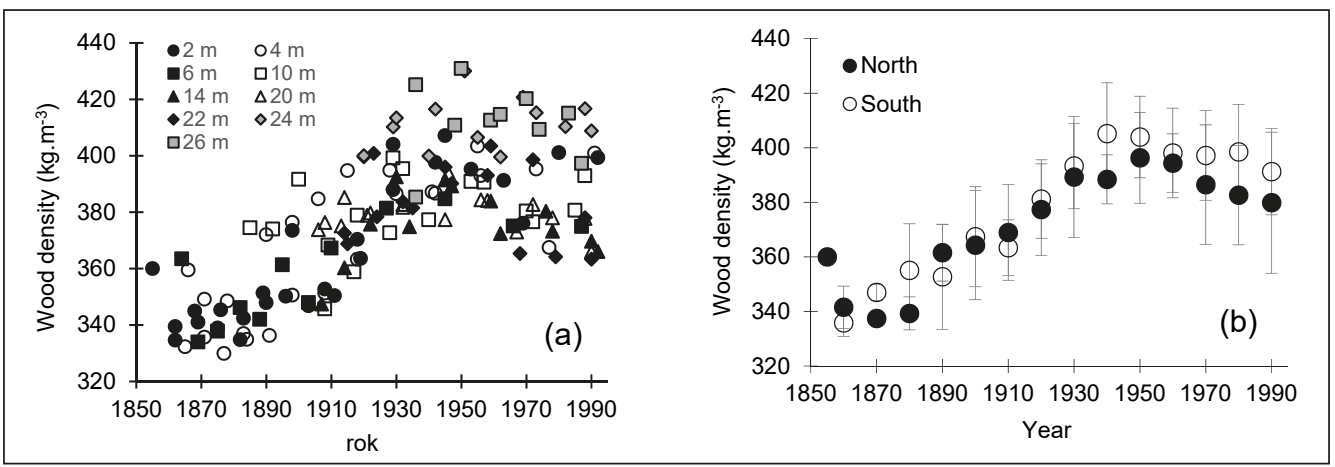

Fig. 3: Variability in wood density along the stem radius for the calendar year - (a) in various height sections, (b) the average values from all height sections with northern and southern orientation (the lines represent \pm 1 standard deviation). 
However, the indicated general trend of wood density variability in spruce only applies to the lower and middle parts of the stem and cannot be applied to the crown part of the stem (Fig. 3a). In this case, the wood density of spruce along the radius does not change or even decreases. This corresponds to the finding that wood density can exceptionally decrease in the circumferential layers of very old trees (Panshin and de Zeeuw 1980).

In the vertical direction, especially in conifers, there is a tendency towards decreasing wood density with as the distance increases from the stem base (Elliott 1970, Zobel and van Buijtenen 1989). This behaviour is representative of Araucaria, Callitris, Larix and Pseudotsuga genera, and some species of Pinus and Abies genera (Panshin and de Zeeuw 1980). However, this trend is not a rule; especially in spruce, there are sometimes opposite tendencies, i.e. towards an increase in wood density along the stem with increasing height (Hakkila 1966, Trendelenburg and Mayer-Wegelin 1955). In our case, the wood density of the monitored sample shows a mixed tendency in both directions (northern and southern orientation) when the density in the stem bottom $(2-6 \mathrm{~m})$ remains almost unchanged and then slightly increases (10-20 m); finally, the crown part of the stem is characterized by a statistically significant increase in values $(\mathrm{p}<0.01)$ (Fig. 4).

The values found for the top part of the stem are of interest when considering that the properties and structure of the stem wood from the crown part are very similar to juvenile wood. Therefore, the concept of "crown-formed wood" was introduced in the early 1960s (Knigge 1960,

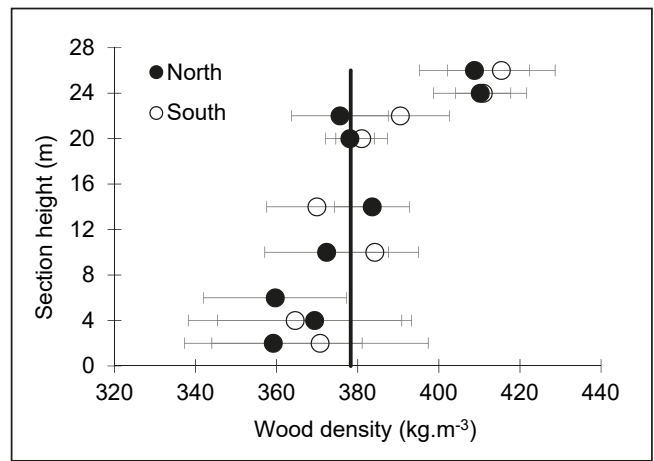

Fig. 4: Variability in wood density along the stem height (the lines represent \pm 1 standard deviation); the vertical line corresponds to the average wood density of the whole stem (378 kg.m $\mathrm{m}^{-3}$ )
Brunden 1964). Juvenile wood differs from mature wood in its anatomical structure (the length of tracheids, orientation of the fibrillar structure in the cell wall) and chemical composition. When expecting juvenile-like wood in the crown of our sample, with gradually increasing density from the pith corresponding to the standard increase in density along the radius (Fig. 3), then the identified opposite trend was surprising.

Wood density is essentially affected by stem convergence. In conifers, the more parallel and less convergent the stem, the smaller change in wood density along the stem height (Spurr and Hsiung 1954). The effect is again related to the representation of juvenile wood. In our case, it is possible to assume pronounced stem convergence in places where the wood density increases with height. This conclusion could be verified by making a comparison with the morphological curve of the stem.

\section{Compression strength parallel to grain - distribution along the stem radius and height}

The average compression strength parallel to grain for the whole tree calculated from all measured specimens was $37.6 \mathrm{MPa}(\mathrm{Sx}=4.2 \mathrm{MPa}$, $\mathrm{Vx}=11.1 \%$ ). This value corresponds to the lower limit of the literal data for dry wood for which, at a moisture content of $12 \%$, various authors indicate a compression strength of 35-79 MPa with a mean value of 40-49 MPa (Vorreiter 1949, Kollman 1951). Irrespective of the section height, the determined variability of the compression strength limit in the direction of the orientation of the fibres was again lower compared to the literal data, which assume $\mathrm{Vx}= \pm 15-20 \%$.

The variability in the mechanical properties of wood is usually estimated from the correlation between wood density and strength. This approach is perfectly justified as it basically proceeds from the correlation between wood strength and cell morphology. There are few studies which focus on monitoring the variability in density and selected mechanical properties of coniferous wood along the stem radius (Panshin and de Zeeuw 1980).

Our analysis tracked the distribution of wood compression strength along the stem radius and height on the same specimens that were used for measuring wood density. This approach then allowed us to determine the relationship between 


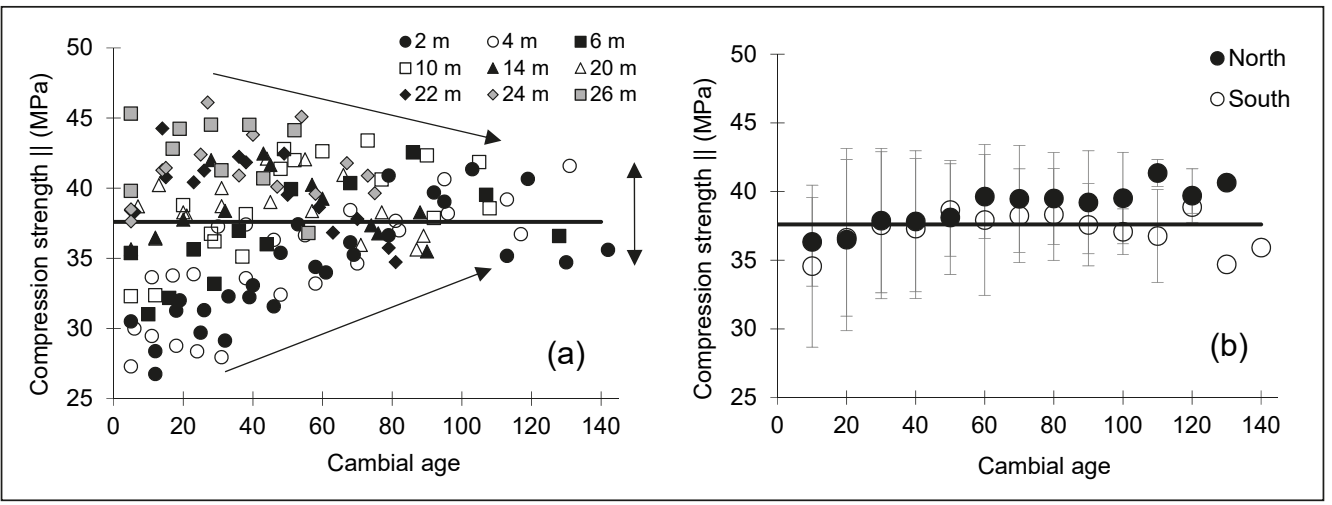

Fig. 5: Variability in compression strength along the stem radius for the average age of the created wood - (a) in various height sections, (b) average values from all height sections with northern and southern orientation (the lines represent \pm 1 standard deviation)

the two variables. Similar to wood density, wood strength also exhibited different trends depending on the methodological approach chosen. Due to the tight theoretical dependence between wood density and strength, we obtained similar results.

As in wood density, wood strength also shows different trends depending on the wood age (Fig. 5a). Again, wood strength increases with age in the stem bottom (a section height of 2-6 m), while a decrease in strength with age is observable in the stem crown part. Similarly, the variability in values decreases with age, whereas the wood strength values are independent of age from the age of 80 years and range around the average value for the entire tree. The difference in strength for the north and south sides is also statistically significantly distinct $(p<0.01)$.
The trend of wood strength in the radial direction in relation to the calendar year of wood formation is shown in Fig. 6. After the initial increase of values since 1950, i.e. at the age of 100 years, the strength decreases. This fact is difficult to explain because the trend does not correspond to adaptation growth or mechanical optimization of the stem with regard to the possible effect of the bending moment. Regarding mountain spruce trees, it is possible to assume that they are exposed to abiotic factors including wind; therefore, we would rather expect maximum wood strength in the surface layer, even if the average tree-ring width were to drop to $1 \mathrm{~mm}$. The differences between the northern and southern orientation of the samples were again statistically significant $(\mathrm{p}<0.001)$.

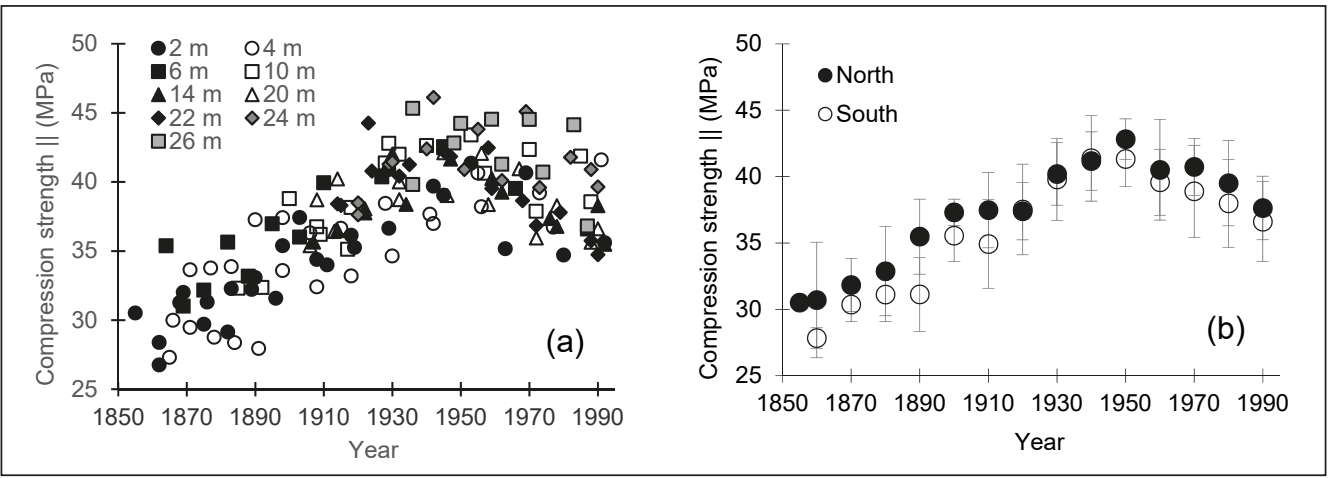

Fig. 6: Variability in compression strength along the stem radius for the calendar year - (a) in various height sections, (b) the average values from all height sections with northern and southern orientation (the lines represent \pm 1 standard deviation) 


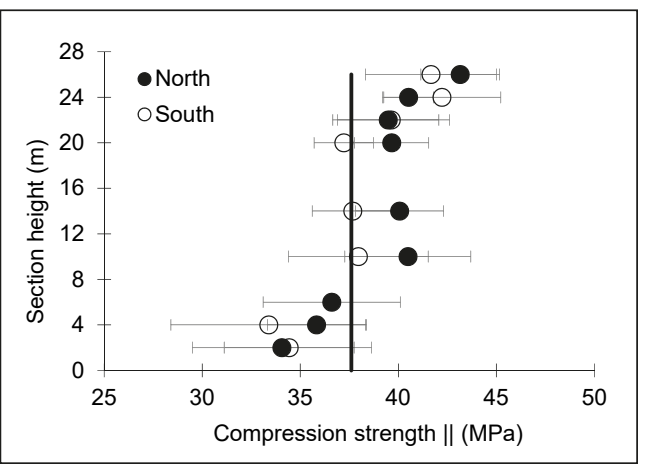

Fig. 7: Variability in compression strength along the stem height (the lines represent \pm 1 standard deviation); the vertical line corresponds to the average compression strength of the whole stem (37.6 MPa).

In the vertical direction, wood strength shows an even more pronounced dependence on the probable shape of the stem expressed by the morphological curve than wood density (Fig. 7), especially in the bottom part of the stem within the height sections of $2-10 \mathrm{~m}$. In this part of the stem, we observed a significant increase in values along the stem height, followed by stagnation in the middle part of the stem up to the height of $20-22 \mathrm{~m}$. The wood strength in sections of the crown layer above $22 \mathrm{~m}$ again shows higher values similar to Fig. 4.

\section{Dependence between compression strength limit in the direction of the orientation of the fibres on wood density}

Due to its ability to express the relative proportion of cellular substance (basic chemical constituents) in a given volume of wood, wood density is the best trait for predicting the mechanical properties of wood, namely wood strength. In general, this dependency is expressed by a power function, but a linear function is sufficient in most cases. For example, Lavers (1969) and Pearson, Gilmore (1980) present a linear function expressing the dependence between the average compression strength parallel to grain and the average density of wood for 41 European and North American wood species in the formula given below:

$$
\sigma=95.0 \rho-1.6\left(R^{2}=0.98\right),
$$

where $\sigma$ is the compression strength parallel to grain (MPa) and $\rho$ is wood density (g.cm $\left.{ }^{-3}\right)$.
Similarly, Kretschmann (1999) describes the dependence of compression strength parallel to grain on density at $\mathrm{w}=12 \%$ as follows:

$$
\sigma=93.7 \rho^{0.97},
$$

where $\sigma$ is the compression strength parallel to grain (MPa) and $\rho$ is wood density $\left(\mathrm{g} . \mathrm{cm}^{-3}\right)$.

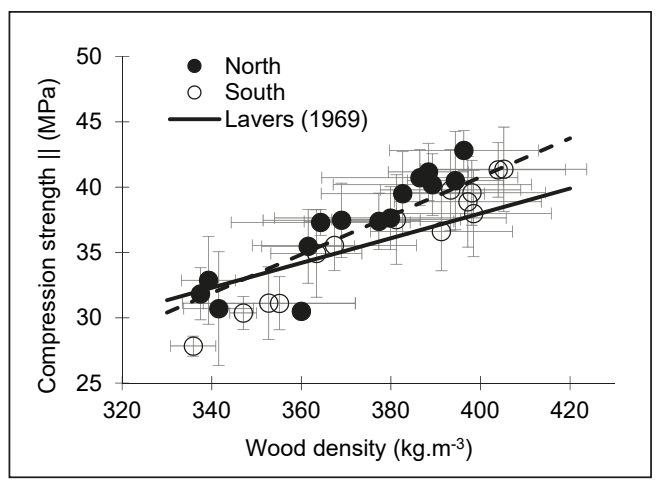

Fig. 8: Dependence of the compression strength parallel to grain on wood density (the horizontal and vertical lines represent \pm 1 standard deviation).

The strength of wood in the direction parallel to fibres was not chosen accidentally, as this stress state involves mechanical action on all the chemical components of the cell wall and thus quantifies their relative representation. The cell wall skeleton is made up of cellulose macromolecules interconnected to a fibrillar structure that is very strong in tension. When the wood is compressed parallel to grain, cellulose is not the only substance that provides its strength; hemicelluloses and lignin also contribute to wood resistance against pressure and buckling.

The dependence of wood strength on density determined by us (Fig. 8) confirms the general positive correlation that shows roughly the same course and variability in both oriented radii $\left(R^{2}=0.63-0.76\right)$. The linear dependence according to Lavers (1969) and Pearson, Gilmor (1980), inserted in the figure, suggests a slightly different course compared to our measured values and differs especially in slope of line. Our linear regression function shows a significantly higher dependence of the strength of wood on its density relative to slope of line being 1.5 times higher than stated in literature (Lavers 1969, Kretschmann 1999). The experimentally established regression relationship takes the following form: 


$$
\sigma=148.2 \rho-18.5\left(R^{2}=0.75\right),
$$

where $\sigma$ is the compression strength parallel to grain (MPa) and $\rho$ is wood density $\left(\mathrm{g} . \mathrm{cm}^{-3}\right)$.

Nevertheless, it can be stated that the determined dependence of both properties is not very different from the theoretical course and that the analysed wood respected the general dependence of properties on anatomical wood structure.

\section{Conclusion}

The selected properties of the analysed sample corresponded to the general trends and values previously reported in literature, with the exception of the atypical behaviour found in the top and circumferential parts of the stem. The results of spatial variability in wood density and compression strength parallel to grain within the stem depended on the method used for their determination. In the case of assigning the density and compression strength of wood to its age (or the order of tree-rings from the pith), there are significant differences in the effect of age for the bottom (an increasing trend with age), middle (no age dependence) and the top part of the stem (a decreasing trend with age). If assigning the wood density and strength to the year (the calendar year in which the wood developed), we obtain a standard dependency pattern - a gradual increase in values with their culmination after about 100 years and a subsequent gradual decline. When determining wood density and strength from the log discs, then we do not find any age trend; we only analyse the variability along the stem height, which is very dependent on stem shape. Regardless of the method chosen, we found that the greater wood density and strength was in the crown part at a distance of 24-26 $\mathrm{m}$ from the stem base. We also found that the wood density variability along the stem height decreases with age whereas wood with similar density and strength in the entire stem is formed from the age of about $80-100$ years. It is significant that the density and strength of wood developed in any given calendar year is not very different in the individual height sections of the stem, except for the highest parts of the stem in the crown area. We demonstrated that wood produced in a given year is similar in its quality expressed by the wood density and compression strength parallel to grain. Furthermore, we demonstrated that there is a dependency of the utility properties of wood on its location within the stem. One probable cause of the trend along the height is the biomechanical optimization of the stem.

The findings of variability in wood density and compression strength parallel to grain are original results. Based on the previous knowledge regarding the influence on wood production by environmental factors, the knowledge of relationships between wood properties allows us to predict and assess the effects of changing environments on the industrial utility properties of wood.

\section{Acknowledgement}

This work was supported by the Ministry of Education, Youth and Sports of CR within the National Sustainability Program I (NPU I), grant number LO1415.

\section{Literature}

Bergsted, A., Olesen, P.O. 2000: Models for predicting dry matter content of Norway spruce. Scandinavian Journal of Forest Research, 15(6): 633-644.

Bodig, J., Jayne, B.A. 1982: Mechanics of Wood. and Wood Composites. Krieger Publishing, 712 pp.

BRUNDEN, M.N. 1964: Specific gravity and fiber length in crown-formed and stem-formed wood. Forest Products Journal, 14:13-17.

DAnborg, F. 1994: Density variation and demarcation of the juvenile wood in Norway spruce. Danish Forest and Landscape Research Institute, Forskningserien,10: 1-78.

ElLiott, G.K. 1970: Wood density in conifers. Technical commentary. $44 \mathrm{pp}$.

Forest Products Laboratory 1999: Wood handbook-Wood as an engineering material. Gen. Tech. Rep. FPL-GTR-113. Madison, WI: U.S. Department of Agriculture, Forest Service, Forest Products Laboratory. 463 p.

Frimbong-Mensah, K. 1987: Fibrelength and basic density variation in the wood of Norway spruce (Picea abies /L./ Karst.) from northern Norway. Communications of the Norwegian Forest Research Institute, 40: 1-25.

GrYc, V. 2003: Vliv polohy ve kmeni na morfologii tracheid u smrku (Picea abies /L.) Karst.). In: MENDELNET 2003: Konference doktorandů LDF MZLU v Brně, 5: 53-58. 
HАккILA, P. 1966: Investigation on the basic density of finish pine, spruce and birch wood. Communicationes Instituti Forestalis Fenniae, 61 (5): 98 pp.

JaAkKola, J.T., Mäkinen, H., SaranpäÄ, P. 2005: Wood density in Norway spruce: changes with thinning intensity and tree age. Canadian Journal of Forest Research, 35(7): 1767-1778.

JoHANsson, K. 1993: Influence of initial spacing and tree class on the basic density of Picea $a b$ ies. Scandinavian Journal of Forest Research, 8(1): 18-27.

Jyske, T., Mäkinen, H., SARAnpäÄ, P. 2008: Wood density within Norway spruce stems. Silva Fennica, 42(3): 439-455.

KnIgGe, W. 1960: The natural variability of wood as it affects selection of test material and structural applications of wood. In: Proceedings World Forestry Congress $5^{\text {th }}, 3$ : 1362-1367.

Kollmann, F. 1951: Technologie des Holzes und der Holzwerkstoffe. 2. Auflage; Springer-Verlag Berlin, Göttingen, Heidelberg, 2233 pp.

LaVers, G.M. 1969: The Strength Properties of Timbers. For. Prod. Res. Bull. 50, HMSO, London.

Luostarinen, K., Pikkarainen, L., Ikonen, V.P., Gerendiain, A.Z., Pulkkinen, P., Peltola, H. 2017: Relationships of wood anatomy with growth and wood density in three Norway spruce clones of Finnish origin. Canadian Journal of Forest Research, 47 (9): 1184-1192.

Molteberg, D., Нøiвø, O. 2006: Development and variation of wood density, kraft pulp yield and fibre dimensions in young Norway spruce (Picea abies). Wood Science and Technology, 40(3): 173-189.

Olesen, P.O. 1976: The interrelation between basic density and ring width of Norway spruce. Det Forstlige Forsøksvaesen $i$ Danmark ,34(4): 339-359.

Olesen, P.O.1977: The variation of the basic density level and tracheid width within the juvenile and mature wood of Norway spruce. Forest Tree Improvement, 12:1-21.

Panshin, A.J., De Zeeuw, C. 1980: Textbook of wood technology. McGraw-Hill, Inc. New York, 736 pp.

Pearson, R.G., Gilmore, R.C. 1980: Effect of fast growth rate on the mechanical properties of loblolly pine. Forest Products Journal, 30 (5): 47-54

Petty, J.A., Macmillan, D.C., Steward, C.M. 1990: Variation of density and growth ring width in stems of Sitka and Norway spruce. Forestry, 63(1): 39-49.
Repola, J. 2006: Models for vertical wood density of Scots pine, Norway spruce and birch stems, and their application to determine average wood density. Silva Fennica, 40(4): 673-685.

SARANPÄÄ, P. 1994. Basic density, longitudinal shrinkage and tracheid length of juvenile wood of Picea abies. Scandinavian Journal of Forest Research, 9(1): 68-74.

SARANPÄÄ, P. 2003. Wood density and growth. In: Barnett, J.R., Jeronimidis, G. (eds.): Wood quality and its biological basis. Blackwell Publishing \& CRC Press, Biological Sciences Series, Bodmin, Great Britain. p. 87-117.

Spurr, S.H., Hsiung, W.-Y. 1954: Growth rate and specific gravity in conifers. Journal of Forestry Research, 52 (3): 191-200.

Trendelenburg, R.H., Mayer-Wegelin, H. 1955: Das Holz als Rohstoff. Hanser Verlag, Munchen, 541 pp.

Tsoumis, G.1991: Science and Technology of Wood: Structure, Properties, Utilization. Structure, Properties, Utilization. Chapman \& Hall, New York, 494 pp.

VORREITER, L. 1949: Holztechnologisches Handbuch. 1. Band, Verlag Georg Fromme \& Co., Wien, 548 pp.

WANGAARD, F.F. 1950: The Mechanical properties of Wood. J. Wiley \& Sons, New York, 377 pp.

Wilhelmsson, L., Arlinger, J., SpÅngberg, K., Lunquist, S.-O., Grahn, T., Hedenberg, Ö., OLsson, L. 2002: Models for predicting wood properties in stems of Picea abies and Pinus sylvestris in Sweden. Scandinavian Journal of Forest Research, 17: 330-350.

Zobel, B.J., VAN BuIJTEnen, J.P. 1989: Wood variations. Its Causes and Control. Springer Series in Wood Science. Springer-Verlag Berlin, London, Tokyo. 363 pp. 